\title{
A RÁKÓCZIFALVA-KASTÉLYDOMBON FELTÁRT BRONZKORI EMBERTANI LELETEK VIZSGÁLATÁNAK EREDMÉNYEI
}

\author{
Hajdu Tamás $^{1,2}$ \\ ${ }^{1}$ Embertani Tanszék, Eötvös Loránd Tudományegyetem, Budapest; \\ ${ }^{2}$ Embertani Tár, Magyar Természettudományi Múzeum, Budapest
}

Hajdu T.: Physical anthropological investigation of human remains excavated at RákóczifalvaKastélydomb Bronze Age site. In 1962, a bi-ritual Bronze Age cemetery (cremation and inhumation burials) were excavated by Zsolt Csalog at Rákóczifalva-Kastélydomb (Jász-NagykunSzolnok county, Hungary). The Early Bronze Age skeletons and cremains belonged to the Nagyrév culture. The Late Bronze Age individuals were the bearers of the so-called Rákóczifalva cultural group of the Tumulus culture. The study provides the results of the biological anthropological analysis of human remains buried at Rákóczifalva-Kastélydomb Bronze Age cemetery. Both the inhumated and the cremated remains were very poorly preserved and fragmented. The low number of the investigable skeletons that belonged to the Nagyrév culture did not allow us to make any conclusions about the Early Bronze Age populations lived at Rákóczifalva. However, the publication of the basic anthropological results is relevant because these metric data are the first published data of the populations of the Nagyrév culture. The age distribution of the Late Bronze Age community shows a high percentage of sub-adults in the cemetery, similar to Jánoshida-Berek Tumulus culture community. In Rákóczifalva material the sex distribution was balanced. The pathological alterations that are usually frequent in almost every prehistoric material were observable in this series too (e.g. degenerative alterations of the spine and joints, porotic hyperostosis and entheseal changes).

Keywords: Bronze Age; Nagyrév culture; Tumulus culture; Biological anthropology; Bioarchaeology.

\section{Bevezetés}

A Jász-Nagykun-Szolnok megyében található Rákóczifalván 1962 májusában és júniusában Csalog Zsolt vezetésével feltárásokat végeztek, amelyek során gepida, avar és honfoglalás kori csontvázas, valamint kora- és késő bronzkori birituális, csontvázas és hamvasztásos rítusú temetkezések kerültek elö. A kora bronzkori leletek a Nagyrév kultúrához, a késő bronzkori leletek a Halomsíros kultúra ún. rákóczifalvi csoportjához sorolhatók (Csalog 1963a, b, Kovács 1981). Az embertani leletek a feltárást követően a József Attila Tudományegyetem Embertani Intézetébe (ma Szegedi Tudományegyetem, Embertani Tanszék) kerültek vizsgálatra és megörzésre.

A gepida, avar és honfoglalás kori sírok vizsgálatának eredményeit Lipták és Marcsik (1975) ismertette. Farkas az 1975-ben elkészült kandidátusi disszertációjához a JATE Embertani Intézete teljes őskori leletanyagát feldolgozta, így a Rákóczifalván 1962-ben feltárt bronzkori emberi maradványokat is, felvázolva ezzel a Dél-Alföld őskorának embertani képét (Farkas 1975). A disszertáció eredményeiből több összefoglaló munka is született (Farkas és Marcsik 1975, Farkas 1976a, b, 1977a, b). A Rákóczifalván Csalog 
által feltárt bronzkori sírok vizsgálatának eredményei ugyanakkor azóta is csak Farkas Gyula kandidátusi disszertációjából ismertek (Farkas 1975).

A temetö történeti embertani feldolgozása során Farkas a leletek Csalog által a feltárási helyszínén elvégzett kultúra szerinti besorolást használta fel. Az azóta eltelt időben ugyanakkor a kora bronzkori Nagyrév kultúra (Csányi 1983) sírjaira vonatkozó elözetes régészeti közlemény megjelent, emellett Kovács Tibor elvégezte a késő bronzkori Halomsíros kultúra sírjaiból feltárt régészeti leletanyag előzetes feldolgozását és régészeti közlésre való előkészítését, amely eredményeit jelen kutatás elvégzése során rendelkezésemre bocsátotta. Kovács Tibor a leletek Csalog által a feltáráson elvégzett régészeti kormeghatározását több esetben pontosította. Az embertani vizsgálatok során a leletek régészeti kultúrába való besorolásánál Csányi (1983) és Kovács közöletlen régészeti alapadatait és korszak szerinti besorolását vettem figyelembe.

A Nagyrév és a Halomsíros kultúra hazánk területén feltárt temetői közül több széria embertani vizsgálata is megtörtént (1. táblázat), de egyik kultúra esetében sem mondható el az, hogy ezekről a csoportokról jelentős mennyiségü embertani adat ismert lenne. Ez különösen hangsúlyozandó a Nagyrév kultúra esetében. Amennyiben a Közép-Tisza vidéket vesszük alapul, ez még kevésbé van így, amely részben az eddig előkerült leletek rossz megtartási állapotával, részben pedig a bronzkori népességek körében gyakran alkalmazott hamvasztásos temetkezési rítussal magyarázható.

Tanulmányomban a Rákóczifalva-Kastélydomb lelőhelyen előkerült bronzkori sírok embertani vizsgálatának eredményeit ismertetem, Farkas taxonómiai eredményeinek figyelembevételével (Farkas 1975).

\section{Anyag és módszer}

A bronzkori sírok embertani anyaga a Szegedi Tudományegyetem Embertani Tanszékének gyüjteményében található.

A meglévő kora bronzkori sírok: 4, 26, 61, 88, 138.

A meglévő késő bronzkori sírok: „D”, 1, 2, 3, 18, 24, 47, 51, 52, 55, 57, 64, 67, 73, $75,82,84,86,89,99,100,103,110,112,113,120 \mathrm{a}, 120 \mathrm{~b}, 125,142,147,148,151,155$, $163,164,170,172,173$.

A meglévő bizonytalan kulturális besorolású, bronzkori sírok: 17, 34, 63, 84, 85, 93, $146,151$.

A morfológiai nem meghatározását Éry és munkatársai (1963) módszere szerint végeztem el. A biológiai életkor becslésére Todd (1920), Schour és Massler (1941), Ubaleker (1978), Stloukal és Hanáková (1978), Ferembach és munkatársai (1979), Işcan és munkatársai $(1984,1985)$, Meindl és Lovejoy (1985), valamint Bernert és munkatársai (2007, 2008) módszerét használtam fel. A koponyák és vázcsontok mérését Martin és Saller (1957) szerint végeztem el. A testmagasság becslését Sjøvold (1990) módszere alapján végeztem el a combcsont és a felkarcsont legnagyobb hosszát, valamint a sípcsont teljes hosszát alapul véve. Az eredmények kiszámítására Bernert (2005) programcsomagját használtam.

A paleopatológiai elemzéseket Ortner (2003), valamint Aufderheide és RodríguezMartín (1998) munkáit figyelembe véve végeztem el.

A hamvasztásos temetkezések csontanyagát Nemeskéri és Harsányi (1968), valamint Pap és munkatársai (2009) útmutatásait figyelembe véve Chochol (1961) alapján végeztem el. 
1. táblázat. A Nagyrév és Halomsíros kultúra embertani leletei a szakirodalomban.

Table 1. Published human remains belonged to the Nagyrév and Tumulus culture (közöletlen: unpublished publication, jelen tanulmány: present publication).

\begin{tabular}{|c|c|c|c|}
\hline $\begin{array}{l}\text { Régészeti } \\
\text { kultúra - } \\
\text { Archaeol. c. }\end{array}$ & $\begin{array}{l}\text { Lelöhely - } \\
\text { Site }\end{array}$ & $\begin{array}{l}\text { Irodalom - } \\
\text { References }\end{array}$ & $\begin{array}{l}\text { Sírszám - } \\
\text { No. of } \\
\text { graves }\end{array}$ \\
\hline \multirow[t]{3}{*}{ Nagyrév } & Szigethalom-Szabadkai út & Zoffmann 1995 & 1 \\
\hline & Szigetszentmiklós-Felsőtag & Zoffmann 1995 & 39 \\
\hline & Rákóczifalva-Kastélydomb & Farkas 1975 & 3 \\
\hline \multirow[t]{21}{*}{ Halomsíros } & $\begin{array}{l}\text { Budapest XXII. ker.-Nagytétény- } \\
\text { Érdliget (M6) }\end{array}$ & $\begin{array}{l}\text { Hajdu 2012a, b; Köhler és } \\
\text { Hajdu közöletlen }\end{array}$ & 45 \\
\hline & Debrecen-Bellegelő & Szathmáry 1979 & 1 \\
\hline & Egyek-Bodajcs-oldal & Szathmáry 1979 & 1 \\
\hline & Egyek-Dorogmai út & Szathmáry 1979 & 3 \\
\hline & Egyek-Tag & Szathmáry 1979 & 2 \\
\hline & Emőd-István major & Kővári és Marcsik 2004 & 1 \\
\hline & Győr-Ménfőcsanak & Tóth és mtsai 2016 & 2 \\
\hline & Jánosháza & Tóth 2013 & 3 \\
\hline & Jánoshida-Berek & Hajdu 2008 & 173 \\
\hline & Katymár-Prispa & Farkas 1975 & 1 \\
\hline & Mezőcsát-Hörcsögös & $\begin{array}{l}\text { Hansel és Kalicz } 1986 \text { cit } \\
\text { Nemeskéri; Hansel és Kalicz } \\
1986 \text { cit Tóth; Hajdu 2012a, b }\end{array}$ & 34 \\
\hline & Mezőnagymihály-Nagyecsér-Észak & Fischl és Hajdu 2016 & 7 \\
\hline & Oszlár-Nyárfaszög & Zoffmann 2005 & 5 \\
\hline & $\begin{array}{l}\text { Rákóczifalva-Bivalytó-Bagi föld } \\
\text { I, 1. lelőhely }\end{array}$ & $\begin{array}{l}\text { Hajdu 2012a, b; Kővári és } \\
\text { Hajdu közöletlen }\end{array}$ & 92 \\
\hline & Rákóczifalva-Községháza & Zoffmann 2004 & 7 \\
\hline & Rákóczifalva-Kastélydomb & $\begin{array}{l}\text { Farkas 1975, Hajdu 2012a, } \\
\text { b, jelen tanulmány }\end{array}$ & 47 \\
\hline & Szurdokpüspöki-Hosszú dűlö & Köhler és Hajdu 2008, 2009 & 3 \\
\hline & Tápé-Széntéglaégető & Farkas és Lipták 1971, 1975 & 579 \\
\hline & Törökszentmiklós-Kengyeltenyősz. & Szathmáry 1979 & 1 \\
\hline & Tiszafüred-Majoroshalom C, E & Hajdu 2012a, b, közöletlen & 149 \\
\hline & Tiszakeszi-Szódadomb & $\begin{array}{l}\text { Kővári 2008; Hajdu 2012a, } \\
\text { b, közöletlen }\end{array}$ & 3 \\
\hline
\end{tabular}

\section{Vizsgálati eredmények}

Az embertani elemzés során nyert alapadatok, az elhalálozottak kor és nem szerinti megoszlása, valamint a metrikus elemzés eredményei a 2-5. táblázatokban láthatók. A hamvasztásos rítusú sírokra vonatkozó elemzés adatait a 6-7. táblázatban foglaltam össze.

A kora bronzkori sírok vizsgálatának eredményei

4. sír (Ltsz. 3517): Csontvázas temetkezés. 35-40 éves férfi. A koponya, az állkapocs és a váz egyaránt töredékes. A koponya rendkívül robusztus, a vázon ez kevésbé volt megfigyelhetö. Az orrüreg alsó peremének alakja anthropin, alveoláris prognathia nincs. A homlok lapos, a nyakszirt ívelt, a fossa canina közepesen mély. Az ágyéki csigolyák kis ízületein gyulladásnyomok láthatók. 
2. táblázat. A vizsgált egyének alapadatai (-: hiányzik, t: töredékes, h: hiányos, th: töredékes és hiányos).

Table 2. Basic data of investigated remains buried at Rákóczifalva Bronze Age cemetery (-: missing, $\mathrm{t}$ : fragmentary, h: incomplete, th: fragmentary and incomplete, csontvázas: inhumated, hamvasztott: cremated).

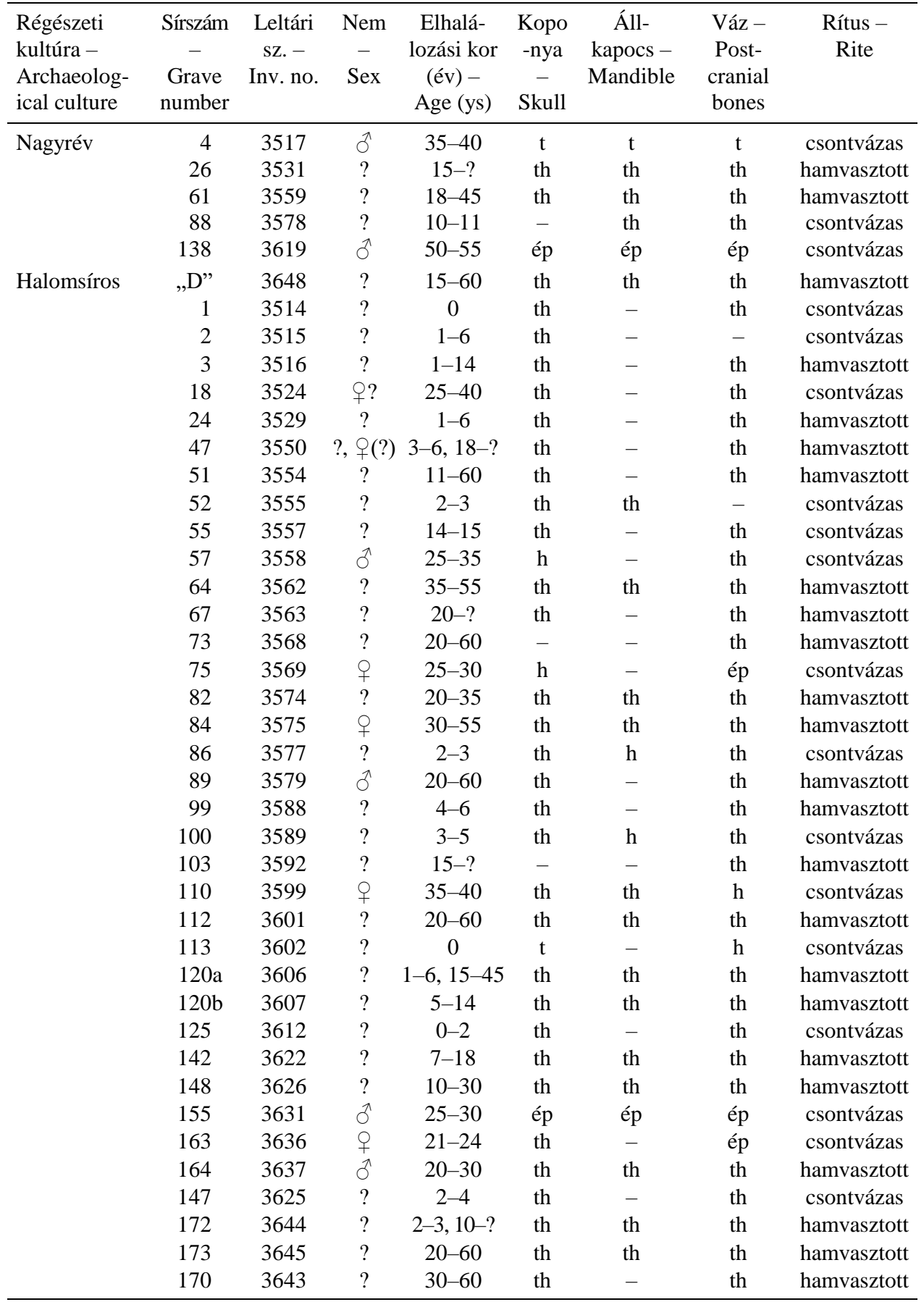


2. táblázat folytatása-Table 2 cont'd.

\begin{tabular}{|c|c|c|c|c|c|c|c|c|}
\hline $\begin{array}{l}\text { Régészeti } \\
\text { kultúra - } \\
\text { Archaeolog- } \\
\text { ical culture }\end{array}$ & $\begin{array}{c}\text { Sírszám } \\
- \\
\text { Grave } \\
\text { number }\end{array}$ & $\begin{array}{c}\text { Leltári } \\
\text { sz. - } \\
\text { Inv. no. }\end{array}$ & $\begin{array}{c}\mathrm{Nem} \\
- \\
\mathrm{Sex}\end{array}$ & $\begin{array}{l}\text { Elhalá- } \\
\text { lozási kor } \\
\text { (év) - } \\
\text { Age (ys) }\end{array}$ & $\begin{array}{c}\text { Kopo } \\
\text {-nya } \\
- \\
\text { Skull }\end{array}$ & $\begin{array}{c}\text { Áll- } \\
\text { kapocs - } \\
\text { Mandible }\end{array}$ & $\begin{array}{l}\text { Váz- } \\
\text { Post- } \\
\text { cranial } \\
\text { bones }\end{array}$ & $\begin{array}{l}\text { Rítus - } \\
\text { Rite }\end{array}$ \\
\hline Nagyrévi - & 17 & 3523 & ๙ & $35-50$ & th & th & $\mathrm{h}$ & csontvázas \\
\hline \multirow[t]{6}{*}{ Halomsíros } & 34 & 3539 & q & $20-30$ & th & th & th & csontvázas \\
\hline & 63 & 3561 & 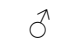 & $40-45$ & ép & $\mathrm{h}$ & th & csontvázas \\
\hline & 85 & 3576 & 우? & $20-25$ & th & th & th & csontvázas \\
\hline & 93 & 3583 & $?$ & $6-7$ & $\mathrm{t}$ & th & $\mathrm{h}$ & csontvázas \\
\hline & 146 & 3624 & $?$ & $2-3$ & th & - & $\mathrm{h}$ & csontvázas \\
\hline & 151 & 3629 & q & $30-35$ & th & th & th & csontvázas \\
\hline
\end{tabular}

3. táblázat. A késő bronzkori egyének nemi és korcsoportonkénti megoszlása.

Table 3. Age and sex distribution of the Late Bronze Age individuals.

\begin{tabular}{lcccc}
\hline Korcsoport - Age groups & $?$ & $\delta$ & + & Együtt - Together \\
\hline Neonatus & 2 & - & - & 2 \\
Infans I. & 11 & - & - & 11 \\
Infans I-II. & 3 & - & - & 3 \\
Infans II. & - & - & - & - \\
Infans - Juvenis & 1 & - & - & 1 \\
Juvenis & - & - & - & - \\
Adultus & - & 3 & 4 & 7 \\
Adultus - Maturus & 5 & 1 & 2 & 8 \\
Maturus & - & - & - & - \\
Senilis & - & - & - & - \\
$?$ & 5 & - & - & 5 \\
Együtt - Together & 27 & 4 & 6 & 37 \\
\hline
\end{tabular}

26. sír (Ltsz. 3531): Hamvasztásos temetkezés. 15-? éves meghatározhatatlan nemü egyén. A kiégettségben a váz különböző részei és a koponya között nincs jelentős eltérés. A kiégetettség tökéletlen, a kalcinált csonttöredékek mérete közepes $(1-5 \mathrm{~cm})$, száma körülbelül 10 darab, tömegük $30 \mathrm{~g}$.

61. sír (Ltsz. 3559): Hamvasztásos temetkezés. 18-45 éves, meghatározhatatlan nemü egyén. A csonttöredékek robuszticitása gyenge, az izomreliefek kifejezettsége közepes. A fragmentáltság mértéke közepes (1-5 cm), a kiégetettség tökéletlen. A koponya kevésbé jól kiégett, mint a váz. A hamvak tömege 448 g, mennyisége meghaladja a 100 darabot.

88. sír (Ltsz. 3578): Csontvázas temetkezés. A koponya hiányzik, az állkapocs és a váz töredékes és hiányos. 10-11 éves gyermek.

138. sír (Ltsz. 3619): Csontvázas temetkezés. 50-55 éves férfi (1. ábra). A koponya, az állkapocs és a váz is ép. A csontok között volt egy infans II. korú gyermek sípcsontja is. A koponya alakja felülnézetben ovoid, a szemüreg kerek, az orr széles, sulcus praenasalis megfigyelhető. A spina nasalis inferior 4. fokozatú, a homlok és a nyakszirt ívelt, a fossa canina közepesen mély. A fogak erősen kopottak. A becsült testmagasság 162,8 cm. Taxonómia: cromagnoid B-cromagnoid A (Farkas 1975). A bal csípöízületben 
jelentős, a bal vállízületben enyhe gyulladás nyoma látható. A bal csípöízületben a combcsont fejének szivacsos állománya a gyulladás következtében több helyen felszívódott (2. ábra). A háti és ágyéki csigolyákon spondylosis deformans, a csigolyaközti porckorong és a hátsó kis ízületek gyulladása alakult ki. Mindkét térdkalácson, mindkét combcsont hátsó felszínén (linea aspera) és kistomporán, a sípcsont hátsó felszínén a felső harmadban (linea musculi solei), a tuberositas tibiae-n és radii-n, a csípőlapátokon a crista iliaca teljes hosszában, valamint a bal sarokcsonton jelentős fizikai megterhelésre utaló enthesopathia látható.

4. táblázat. A koponyák antropometriai jellemzői, Jánoshida-Berek.

Table 4. Measurements and indices of the skull, Jánoshida-Berek.

\begin{tabular}{|c|c|c|c|c|c|c|c|}
\hline \multirow{3}{*}{$\begin{array}{r}\text { Régészeti kultúra - Archaeol. culture } \\
\text { Sírszám - Grave no. } \\
\text { Leltári szám - Inventory no. }\end{array}$} & \multicolumn{2}{|c|}{ Nagyrév } & \multicolumn{2}{|c|}{ Halomsíros } & \multicolumn{3}{|c|}{ Nagyrév/Halomsíros } \\
\hline & \multirow{3}{*}{$\begin{array}{c}4 \\
3517 \\
\hat{0}\end{array}$} & \multirow{3}{*}{$\begin{array}{c}138 \\
3619 \\
0\end{array}$} & \multirow{3}{*}{$\begin{array}{c}57 \\
3558 \\
0\end{array}$} & \multirow{3}{*}{$\begin{array}{c}155 \\
3631 \\
0\end{array}$} & \multirow{3}{*}{$\begin{array}{c}34 \\
3539 \\
9 \\
+\end{array}$} & \multirow{3}{*}{$\begin{array}{c}63 \\
3561 \\
\delta\end{array}$} & \multirow{3}{*}{$\begin{array}{c}151 \\
3629 \\
q\end{array}$} \\
\hline & & & & & & & \\
\hline Martin no. $\quad$ Nem - Sex & & & & & & & \\
\hline 1 & - & 176 & - & 188 & - & 191 & - \\
\hline 5 & - & 106 & - & 105 & - & 103 & - \\
\hline 8 & - & - & - & 141 & - & 148 & - \\
\hline 9 & - & 100 & 98 & 97 & - & 106 & - \\
\hline 10 & - & 122 & - & 108 & - & - & - \\
\hline 11 & - & 120 & - & 119 & - & 122 & - \\
\hline 12 & - & - & 112 & 120 & - & 123 & - \\
\hline 17 & - & 136 & - & 138 & - & 142 & - \\
\hline 20 & - & - & - & - & - & 119 & - \\
\hline 38 & - & - & - & 1443 & - & 1587,2 & - \\
\hline 40 & - & 94 & - & 99 & - & 91 & - \\
\hline 43 & - & 108 & 103 & 104 & - & 113 & - \\
\hline 45 & - & 135 & - & 130 & - & 142 & - \\
\hline 46 & - & 97 & - & 87 & - & 98 & - \\
\hline 47 & - & 107 & - & 117 & - & 131 & - \\
\hline 48 & - & 66 & - & 69 & - & 79 & - \\
\hline 51 & - & 40 & - & 40 & - & 43 & - \\
\hline 52 & - & 34 & - & 32 & - & 37 & - \\
\hline 54 & - & 27 & - & 24 & - & 25 & - \\
\hline 55 & - & 49 & - & 48 & - & 57 & - \\
\hline 62 & - & - & - & 46 & - & 47 & - \\
\hline 63 & - & 36 & - & 39 & - & 37 & - \\
\hline 65 & - & 126 & - & 113 & - & - & - \\
\hline 66 & - & 102 & - & 97 & - & - & - \\
\hline 69 & 35 & 32 & - & 33 & 35 & 36 & (d) 50 \\
\hline 70 & 59 & - & - & 64 & 59 & - & (d) 32 \\
\hline 71 & 35 & 32 & - & 28 & 35 & - & - \\
\hline
\end{tabular}

A késö bronzkori sírok vizsgálatának eredményei

„D”. sír (Ltsz. 3648): Hamvasztásos temetkezés. 15-60 éves meghatározhatatlan nemü egyén. A csontok robuszticitása és az izomreliefek kifejezettsége közepes. A töredezettség mértéke közepes $(1-5 \mathrm{~cm})$, a kiégetettség részenként tökéletes. A 
kiégettségben nincs jelentős eltérés a váz és a koponya különböző részei között. A kalcinált csontok tömege $134 \mathrm{~g}$, mennyisége 10 és 50 darab közötti.

1. sír (Ltsz. 3514): Csontvázas temetkezés. Újszülött. Koponya- és vázcsont töredékek.

2. sír (Ltsz. 3515): A régészeti dokumentáció szerint hamvasztásos temetkezés, ezzel szemben a csontokon égésnyom nem látható. Infans I. korú (1-6 éves) gyermek. A koponya töredékes és hiányos, az állkapocs és a váz hiányzik.

3. sír (Ltsz. 3516): Hamvasztásos temetkezés. 1-14 éves gyermek csonttöredékei. A töredezettség mértéke közepes $(1-5 \mathrm{~cm})$, a kiégetettség tökéletlen. A kiégettségben nincs jelentős eltérés a váz és a koponya különböző részei között. A hamvak tömege $10 \mathrm{~g}$, a kalcinált csontok mennyisége körülbelül 10 darab.

18. sír (Ltsz. 3524): Csontvázas temetkezés. 25-40 éves nö(?). Töredékes és hiányos koponya és váz, az állkapocs hiányzik. A szemüreg szögletes, az orr keskeny, az orrüreg alsó peremén sulcus praenasalis látható, a fossa canina sekély.

24. sír (Ltsz. 3529): Hamvasztásos temetkezés. Infans I. korú (1-6 éves) gyermek. A fragmentáltság mértéke közepes $(1-5 \mathrm{~cm})$, a kiégetettség részenként tökéletes. A koponya kevésbé jól kiégett, mint a váz. A kalcinált csontok tömege 46 g, mennyisége körülbelül 50 darab.

47. sír (Ltsz. 3550): Hamvasztásos temetkezés. 3-6 éves gyermek és egy 18-x éves nő(?). A csontok robuszticitása, az izomreliefek kifejezettsége gyenge. A fragmentáltság mértéke közepes $(1-5 \mathrm{~cm})$, a kiégetettség tökéletlen. A koponya kevésbé kiégett, mint a váz. A kalcinált csontok mennyisége meghaladja a 100 darabot, tömegük $462 \mathrm{~g}$.

51. sír (Ltsz. 3554): Hamvasztásos temetkezés. 11-60 év közötti meghatározhatatlan nemü egyén. A csontok robuszticitása és az izomreliefek kifejezettsége gyenge. A töredezettség mértéke közepes $(1-5 \mathrm{~cm})$, a kiégetettség krétaszerü. A kiégettségben a váz és a koponya különböző részei között jelentős eltérés nem figyelhető meg. A kalcinált csontok tömege $200 \mathrm{~g}$, mennyisége körülbelül 50 darab.

52. sír (Ltsz. 3555): Csontvázas temetkezés. 2-3 éves gyermek. A koponya és az állkapocs töredékes és hiányos, a váz hiányzik.

55. sír (Ltsz. 3557): Csontvázas temetkezés. 14-15 éves egyén. A koponya és a váz töredékes és hiányos, az állkapocs hiányzik.

57. sír (Ltsz. 3558): Csontvázas temetkezés. 25-35 éves férfi (3. ábra). Hiányos koponya, töredékes, hiányos váz. Az állkapocs hiányzik. A koponya alakja felülnézetben ovális, a homlok és a nyakszirt ívelt, a szemüreg szögletes. Az ágyéki és a nyaki csigolyákon enyhe peremképződés látható, a vázon az izomtapadási helyek kifejezettek. Varratcsont jött létre a lambdavarrat jobb oldalán.

64. sír (Ltsz. 3562): Hamvasztásos temetkezés. 35-55 éves meghatározhatatlan nemü egyén. A csontok robuszticitása és az izomreliefek kifejezettsége közepes. A töredezettség mértéke közepes $(1-5 \mathrm{~cm})$, a kiégetettség részenként tökéletes. A koponya tökéletesen, a csípőtájék és az ágyéki csigolyák kevésbé jól kiégettek. A kalcinált csontok mennyisége meghaladja a 100 darabot, tömege $380 \mathrm{~g}$.

67. sír (Ltsz. 3563): Hamvasztásos temetkezés. Felnőtt korú, meghatározhatatlan nemü egyén. A csontok robuszticitása és az izomreliefek kifejezettsége közepes. A töredezettség mértéke közepes (1-5 cm), a kiégetettség a tökéletestől a krétaszerüig változik. A koponya és a medencetájék kiégettsége kevésbé tökéletes, mint a váz többi részéé. A kalcinált csontok tömege 384 g, mennyisége körülbelül 50 darab. 

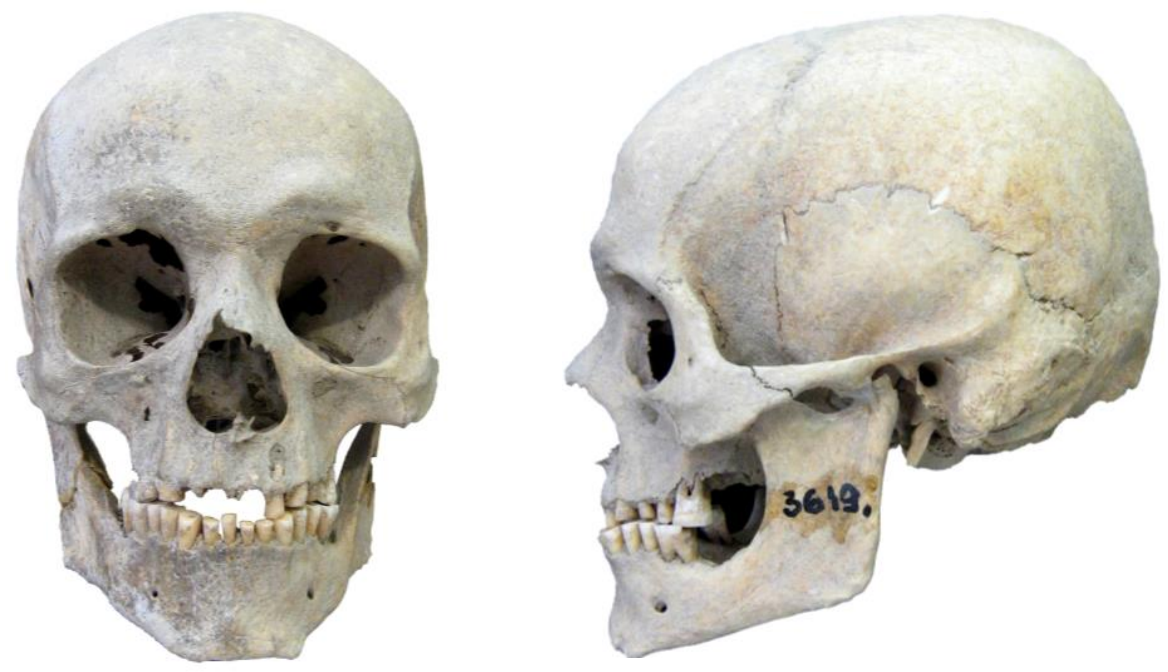

1. ábra: Rákóczifalva-Kastélydomb 138. sír (Ltsz. 3619), Nagyrév kultúra. 50-55 éves férfi, elöl- és oldalnézet.

Fig. 1: Rákóczifalva-Kastélydomb, Grave 138 (Inv. No. 3619), Nagyrév culture, 50-55-year old male, frontal and lateral view.

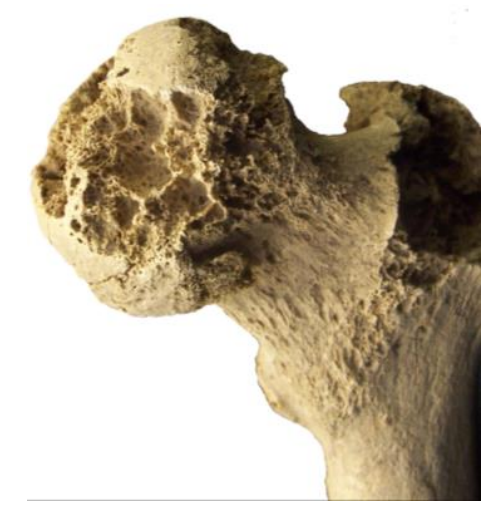

2. ábra: Rákóczifalva-Kastélydomb 138. sír (Ltsz. 3619), Nagyrév kultúra. 50-55 éves férfi. Gyulladás a combcsont fején.

Fig. 2: Rákóczifalva-Kastélydomb, Grave 138 (Inv. No. 3619), Nagyrév culture, 50-55-year old male, inflammation on the femoral head.

73. sír (Ltsz. 3568): Hamvasztásos temetkezés. Felnőtt korú, meghatározhatatlan nemü egyén. A csontok robuszticitása és az izomreliefek kifejezettsége erős. A töredezettség mértéke közepes $(1-5 \mathrm{~cm})$, a kiégetettség részenként tökéletes. A koponya és az alsó végtag csontjainak kiégetettsége tökéletes, a mellkas kevésbé jól kiégett. A kalcinált csontok tömege $160 \mathrm{~g}$, mennyisége 10 és 50 darab közötti.

75. sír (Ltsz. 3569): Csontvázas temetkezés. 25-35 éves nő. A koponya hiányos, a váz ép. A nyakszirt ívelt. A becsült testmagasság $154,0 \mathrm{~cm}$. 

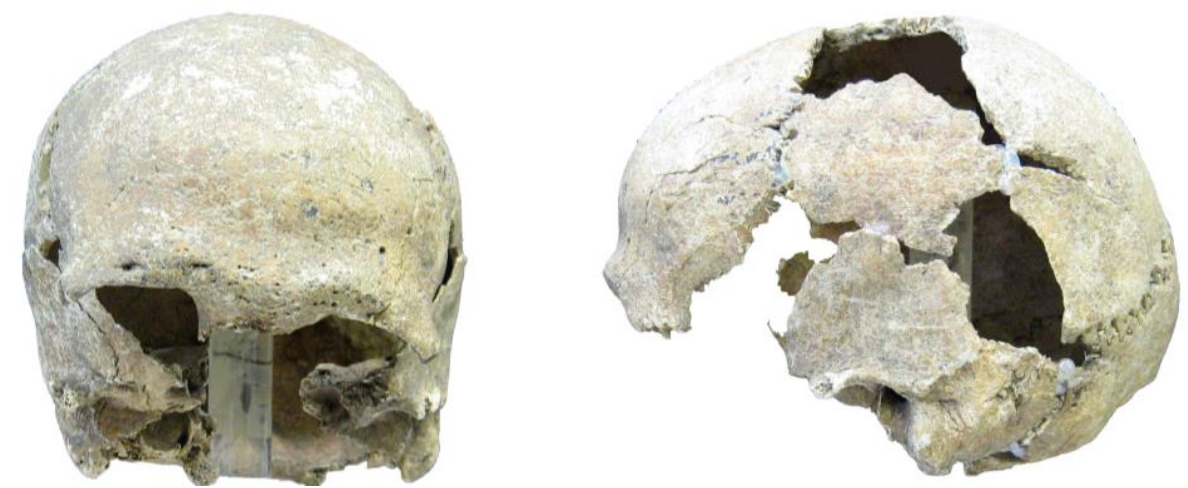

3. ábra: Rákóczifalva-Kastélydomb, 57. sír (Ltsz. 3558), adultus korcsoportú férfi. Halomsíros kultúra, elöl- és oldalnézet.

Fig. 3: Rákóczifalva-Kastélydomb, Grave 57 (Inv. No. 3558), adult male, Tumulus culture, frontal and lateral view of the skull.

5. táblázat. A vizsgált egyének vázcsontjainak metrikus adatai, Rákóczifalva-Kastélydomb. Table 5. The metric data of the long bones, Rákóczifalva-Kastélydomb.

\begin{tabular}{|c|c|c|c|c|c|c|c|c|c|c|c|c|c|}
\hline \multirow{2}{*}{\multicolumn{3}{|c|}{$\begin{array}{l}\text { Régész. Kult. - Archaeol. cult. } \\
\text { Sírszám - Grave no. }\end{array}$}} & \multicolumn{2}{|c|}{ Nagyrév } & \multicolumn{7}{|c|}{ Halomsíros } & \multicolumn{2}{|c|}{ Nagyrév - Haloms. } \\
\hline & & & $4^{\circ 0}$ & 138 & 18 & 38 & 54 & 75 & 110 & 151 & 163 & 17 & 34 \\
\hline & Leltári sz. - & nv. no. & 35173 & 36193 & 3524 & 3631 & 3558 & $3569 ?$ & $3599 ?$ & 3629 & 3636 & 3523 & 3539 \\
\hline & Nem & - Sex & $\delta$ & $\hat{\sigma}$ & $\hat{\sigma}$ & $\hat{0}$ & $\hat{0}$ & 우 & ㅇ & q & o & $\hat{0}$ & q \\
\hline \multirow{6}{*}{$\begin{array}{l}\frac{\pi}{J} \\
\stackrel{0}{\Xi} \\
\frac{\pi}{U}\end{array}$} & \multirow{2}{*}{1} & $\mathrm{~d}$ & - & - & - & - & 144 & 134 & - & - & - & - & - \\
\hline & & s & - & - & - & - & - & - & - & - & - & - & - \\
\hline & \multirow[b]{2}{*}{6} & $\mathrm{~d}$ & 42 & - & - & - & 36 & 34 & - & - & - & - & - \\
\hline & & s & - & - & - & - & 41 & - & - & - & - & - & - \\
\hline & \multirow{2}{*}{$6: 1$} & $\mathrm{~d}$ & - & - & - & - & 25,00 & 25,37 & - & - & - & - & - \\
\hline & & $\mathrm{s}$ & - & - & - & - & - & - & - & - & - & - & - \\
\hline & \multirow{2}{*}{1} & $\mathrm{~d}$ & - & 303 & - & 304 & - & 296 & - & - & - & - & - \\
\hline & & $\mathrm{s}$ & - & 303 & - & 301 & - & - & - & - & - & - & - \\
\hline & \multirow[b]{2}{*}{2} & d & - & 301 & - & 290 & - & 295 & - & - & - & - & - \\
\hline & & s & - & 302 & - & 297 & - & - & - & - & - & - & - \\
\hline & & $\mathrm{d}$ & - & 46 & - & 50 & - & 420 & - & 45 & - & - & - \\
\hline & 3 & $\mathrm{~s}$ & - & 46 & - & 47 & 49 & - & - & 43 & - & - & - \\
\hline \multirow{12}{*}{$\begin{array}{l}\stackrel{0}{己} \\
\text { 总 } \\
\text { 至 }\end{array}$} & \multirow[t]{2}{*}{4} & d & 61 & 61 & - & - & - & 540 & 54 & - & - & - & - \\
\hline & & $\mathrm{s}$ & - & 62 & - & 65 & - & 540 & 51 & - & - & 70 & - \\
\hline & \multirow[b]{2}{*}{5} & $\mathrm{~d}$ & 23 & 23 & - & 22 & - & 23 & 20 & - & 18 & 23 & - \\
\hline & & s & 22 & 23 & - & 20 & 23 & 22 & 20 & 20 & 18 & 29 & - \\
\hline & \multirow{2}{*}{6} & $\mathrm{~d}$ & 18 & 18 & - & 18 & - & 16 & 17 & - & 15 & 18 & - \\
\hline & & s & 18 & 18 & - & 17 & 17 & 17 & 17 & - & 15 & 18 & - \\
\hline & \multirow[b]{2}{*}{7} & $\mathrm{~d}$ & 65 & 62 & - & 63 & - & 59 & 59 & - & 52 & 61 & - \\
\hline & & $\mathrm{s}$ & 64 & 65 & - & 63 & 62 & 60 & 59 & - & 54 & 61 & - \\
\hline & \multirow{2}{*}{$7: 1$} & $\mathrm{~d}$ & -2 & 20,46 & -2 & 20,72 & - & 19,93 & - & - & - & - & - \\
\hline & & s & -2 & 21,45 & -2 & 20,93 & - & - & - & - & - & - & - \\
\hline & \multirow{2}{*}{$6: 5$} & $\mathrm{~d}$ & $78,26^{\prime}$ & 78,26 & $-\varepsilon$ & 81,82 & - & $69,57 \varepsilon$ & 85,00 & - & 83,33 & 78,26 & - \\
\hline & & $\mathrm{s}$ & $81,82^{\circ}$ & 78,26 & - & 85,00 & 73,91 & $77,27 \varepsilon$ & 85,00 & - & 83,33 & 62,07 & - \\
\hline
\end{tabular}


5. táblázat folytatása. - Table 5 cont'd.

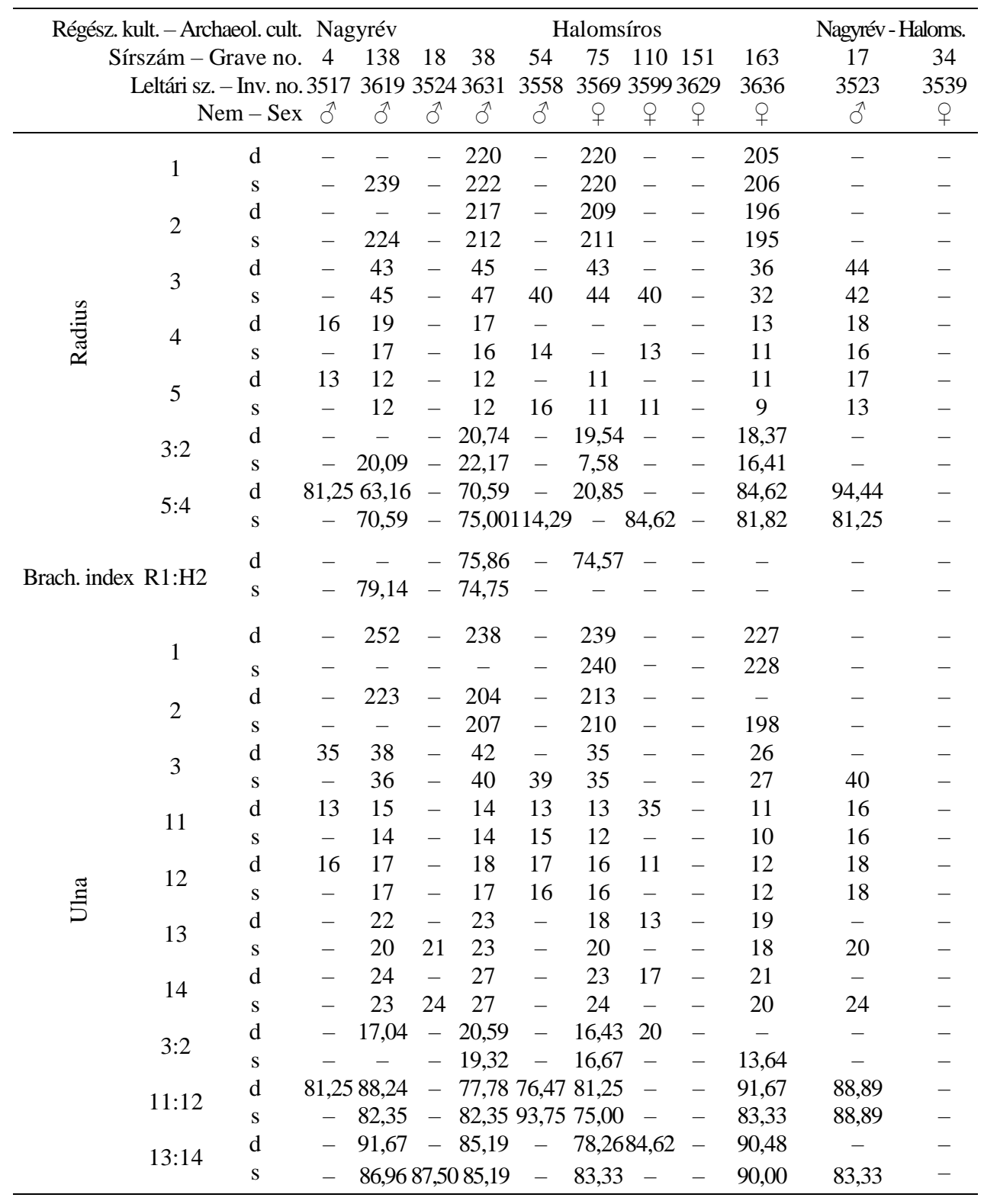

82. sír (Ltsz. 3574): Hamvasztásos temetkezés. 20-35 éves, meghatározhatatlan nemű egyén. A csontok robuszticitása és az izomreliefek kifejezettsége közepes. A töredezettség mértéke közepes (1-5 cm), a kiégetettség részenként tökéletes. A medencetájék kevésbé kiégett, mint a váz többi része. Az égett csonttöredékek tömege 695 g, mennyisége meghaladja a 100 darabot. 
5. táblázat folytatása. - Table 5 cont'd.

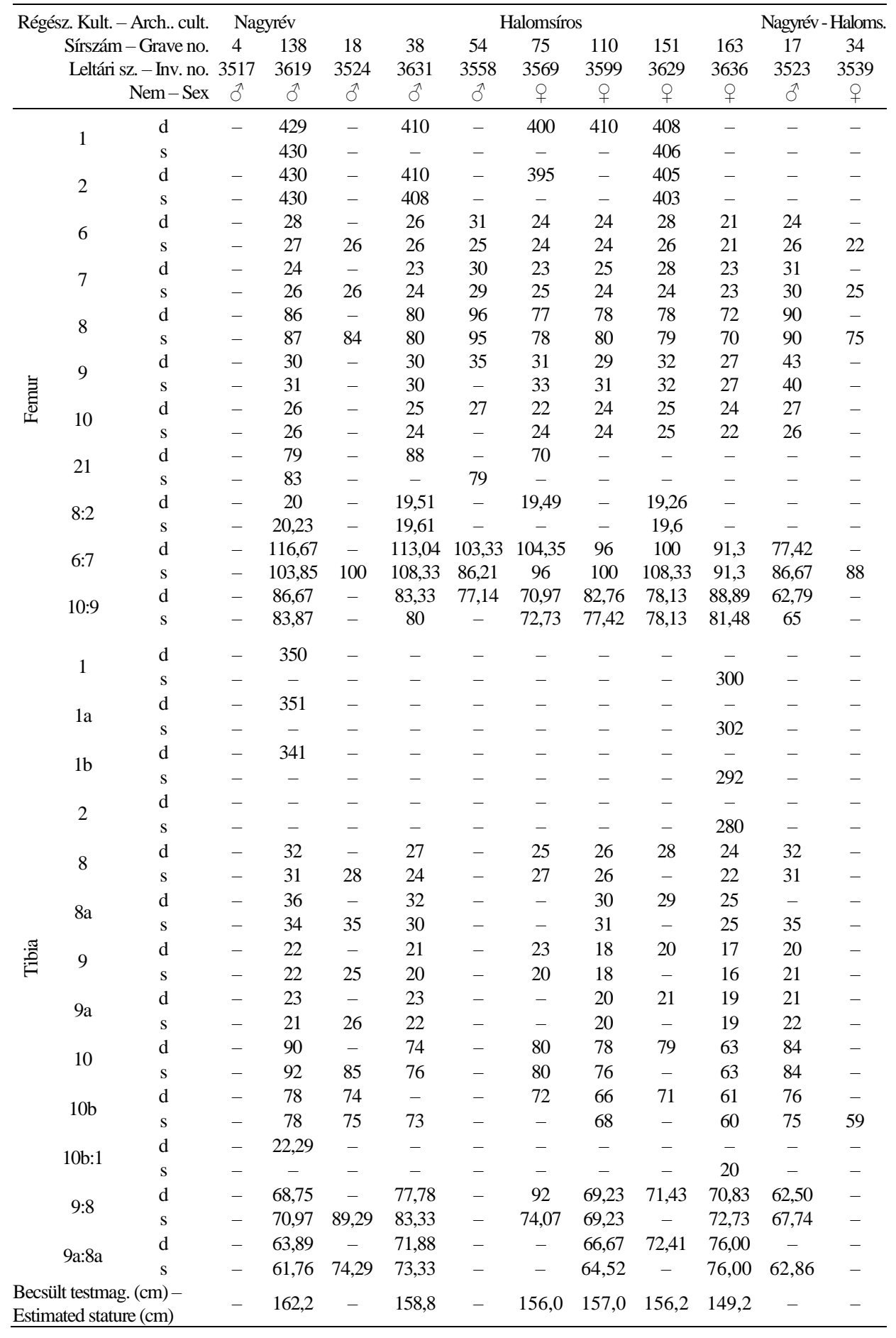


84. sír (Ltsz. 3575): Hamvasztásos temetkezés. 30-55 éves nö. A csonttöredékek robuszticitása és az izomreliefek kifejezettsége gyenge. A töredezettség mértéke közepes $(1-5 \mathrm{~cm})$, a kiégetettség tökéletes. A medencetájék kiégettsége kevésbé tökéletes, mint a váz többi részéé. A kalcinált csontok tömege $436 \mathrm{~g}$, mennyisége körülbelül 50 darab.

86. sír (Ltsz. 3577): Csontvázas sír. 2-3 éves gyermek. A koponya és a váz töredékes és hiányos, az állkapocs hiányos. A koronavarrat jobb oldalán, a nyílvarrat lambda mérőponthoz közeli részén, valamint a lambdavarrat jobb oldalán egyaránt egy-egy közepes méretü varratcsont figyelhető meg. A bal falcsonton poroticus fázisú cribra cranii alakult ki.

6. táblázat. A hamvasztásos temetkezések vizsgálatának eredményei. Table 6. Results of the examination of cremation burials.

\begin{tabular}{|c|c|c|c|c|c|c|c|}
\hline \multirow{2}{*}{$\begin{array}{l}\text { Régészeti k. - Arch. c. } \\
\text { Sírszám-Grave no. }\end{array}$} & & \multicolumn{2}{|c|}{ Nagyrév } & \multicolumn{4}{|c|}{ Halomsíros } \\
\hline & & 26 & 61 & $\mathrm{D}$ & 3 & 47 & 51 \\
\hline Rítus - Rite & $\begin{array}{l}\text { Egy egyén - One } \\
\text { person } \\
\text { Két egyén - Two } \\
\text { persons } \\
\text { Nem vizsgálható - } \\
\text { Non-examinable }\end{array}$ & + & + & + & + & + & + \\
\hline $\begin{array}{l}\text { Töredezettség } \\
\text { mértéke - Measure } \\
\text { of fragments }\end{array}$ & $\begin{array}{l}x-1 \mathrm{~cm} \\
1-5 \mathrm{~cm} \\
5-x \mathrm{~cm}\end{array}$ & + & + & + & + & + & + \\
\hline $\begin{array}{l}\text { A kiégettség mértéke } \\
\text { - Burning level }\end{array}$ & $\begin{array}{l}\text { Krétaszerü - Cretaceous } \\
\text { Tökéletestől krétaszerüig- } \\
\text { From perfect to cretac. } \\
\text { Tökéletes - Perfect } \\
\text { Részenként tökéletes - } \\
\text { Perfect in parts } \\
\text { Tökéletlen - Imperfect }\end{array}$ & + & + & + & + & + & + \\
\hline $\begin{array}{l}\text { Mennyiség (db) - } \\
\text { Quantity (pieces) }\end{array}$ & $\begin{array}{l}\mathrm{x}-10 \\
10-50 \\
\approx 50 \\
100-\mathrm{x}\end{array}$ & + & + & + & + & + & + \\
\hline $\begin{array}{l}\text { Robuszticitás - } \\
\text { Robusticity }\end{array}$ & $\begin{array}{l}\text { Gyenge - Weak } \\
\text { Közepes - Medium } \\
\text { Kiemelkedő - Strong } \\
\text { Erőteljes - Very } \\
\text { strong } \\
\text { Nem vizsgálható - } \\
\text { Non-examinable }\end{array}$ & + & + & + & + & + & + \\
\hline $\begin{array}{l}\text { Izomreliefek - } \\
\text { Muscle attachment } \\
\text { sites }\end{array}$ & $\begin{array}{l}\text { Gyenge - Weak } \\
\text { Közepes - Medium } \\
\text { Erős - Strong } \\
\text { Nem vizsgálható - } \\
\quad \text { Non-examinable }\end{array}$ & + & + & + & + & + & + \\
\hline Tömeg - Weight (g) & & 30 & 448 & 134 & 10 & 462 & 200 \\
\hline
\end{tabular}


6. táblázat folytatása - Table 6 cont'd.

\begin{tabular}{|c|c|c|c|c|c|c|c|}
\hline \multirow{2}{*}{$\begin{array}{l}\text { Régészeti k. - Arch. c. } \\
\text { Sírszám - Grave no. }\end{array}$} & & \multicolumn{6}{|c|}{ Halomsíros } \\
\hline & & 64 & 67 & 73 & 82 & 89 & 99 \\
\hline Rítus - Rite & $\begin{array}{l}\text { Egy egyén - One } \\
\text { person } \\
\text { Két egyén - Two } \\
\text { persons } \\
\text { Nem vizsgálható - } \\
\text { Non-examinable }\end{array}$ & + & + & + & + & + & + \\
\hline $\begin{array}{l}\text { Töredezettség } \\
\text { mértéke - Measure } \\
\text { of fragments }\end{array}$ & $\begin{array}{l}\mathrm{x}-1 \mathrm{~cm} \\
1-5 \mathrm{~cm} \\
5-\mathrm{x} \mathrm{cm}\end{array}$ & + & + & + & + & + & + \\
\hline $\begin{array}{l}\text { A kiégettség mértéke } \\
\text { - Burning level }\end{array}$ & $\begin{array}{l}\text { Krétaszerü-Cretaceous } \\
\text { Tökéletestől krétaszerüig- } \\
\text { From perfect to cretac. } \\
\text { Tökéletes - Perfect } \\
\text { Részenként tökéletes - } \\
\text { Perfect in parts } \\
\text { Tökéletlen - Imperfect }\end{array}$ & + & + & + & + & + & + \\
\hline $\begin{array}{l}\text { Mennyiség (db) - } \\
\text { Quantity (pieces) }\end{array}$ & $\begin{array}{l}\mathrm{x}-10 \\
10-50 \\
\approx 50 \\
100-\mathrm{x}\end{array}$ & + & + & + & + & + & + \\
\hline $\begin{array}{l}\text { Robuszticitás - } \\
\text { Robusticity }\end{array}$ & $\begin{array}{l}\text { Gyenge - Weak } \\
\text { Közepes - Medium } \\
\text { Kiemelkedő - Strong } \\
\text { Eröteljes - Very strong } \\
\text { Nem vizsgálható - } \\
\quad \text { Non-examinable }\end{array}$ & + & + & + & + & + & + \\
\hline $\begin{array}{l}\text { Izomreliefek - } \\
\text { Muscle attachment } \\
\text { sites }\end{array}$ & $\begin{array}{l}\text { Gyenge - Weak } \\
\text { Közepes - Medium } \\
\text { Erös - Strong } \\
\text { Nem vizsgálható - } \\
\text { Non-examinable }\end{array}$ & + & + & + & + & + & + \\
\hline Tömeg - Weight (g) & & 380 & 384 & 160 & 695 & 248 & 8 \\
\hline
\end{tabular}

89. sír (Ltsz. 3579): Hamvasztásos temetkezés. 20-60 éves férfi. A felsőarc rendkívül robusztus. A váz robuszticitása és az izomreliefek kifejezettsége erős. A fragmentáltság mértéke közepes $(1-5 \mathrm{~cm})$, a kiégetettség részenként tökéletes. A koponya és az alsó végtagok kevésbé jól kiégetettek, mint a váz többi része. A hamvak tömege 248 g, a kalcinált csontok mennyisége 10 és 50 darab közötti.

99. sír (Ltsz. 3588): Hamvasztásos temetkezés. 4-6 éves gyermek. A töredezettség mértéke kicsi (1 cm-es, és annál kisebb csonttöredékek), a kiégetettség tökéletes. Az alkarcsontok kevésbé kiégettek, mint a koponya, vagy a váz többi része. A hamvak tömege 8 g, a kalcinált csontok mennyisége körülbelül 10 darab. 
6. táblázat folytatása - Table 6 cont'd

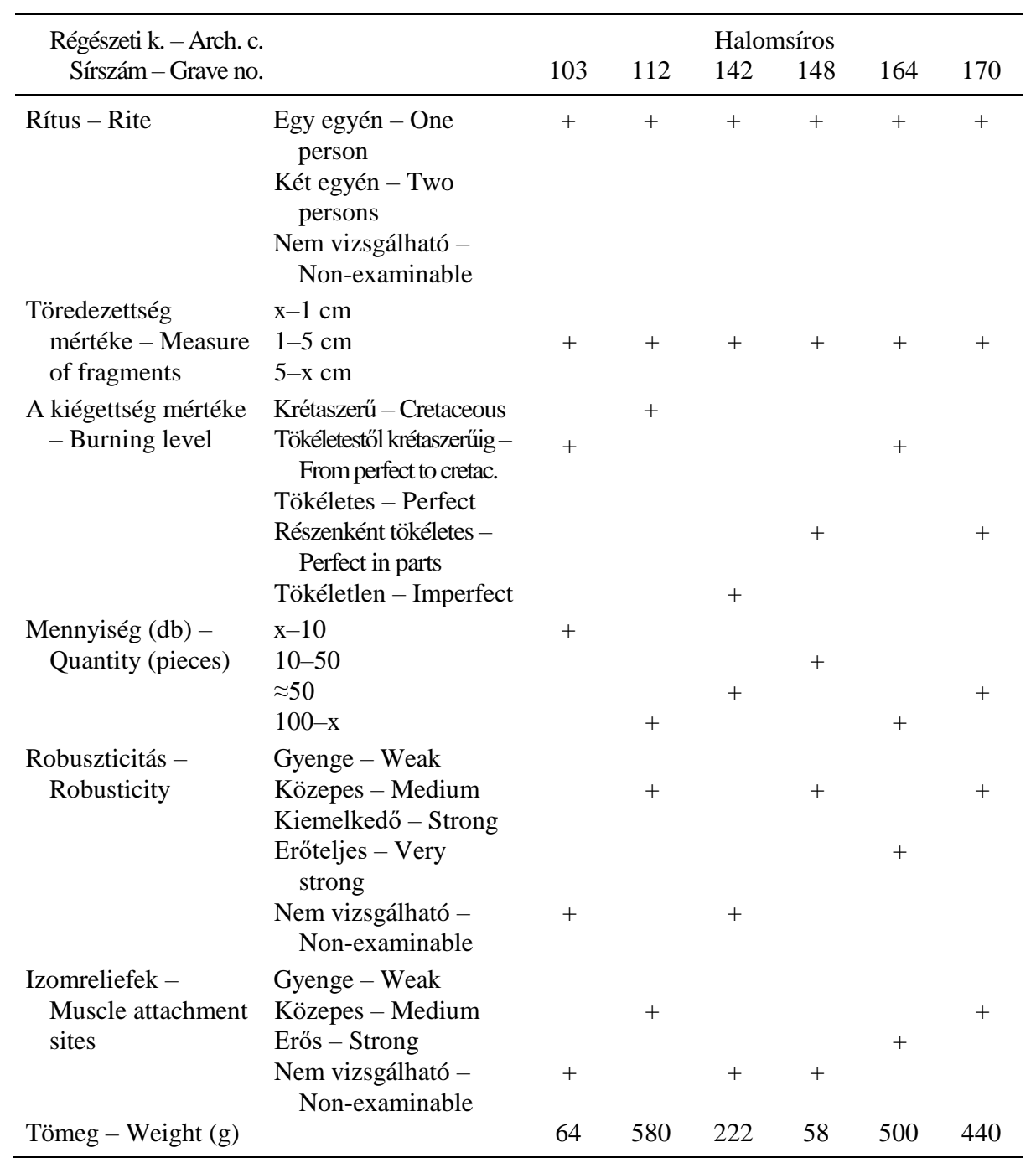

100. sír (Ltsz. 3589): Csontvázas temetkezés. 3-5 éves gyermek. Töredékes és hiányos koponya és váz, hiányos állkapocs. A jobb szemüregben cribroticus fázisú cribra orbitalia, a jobb falcsonton poroticus fázisú cribra cranii látható.

103. sír (Ltsz. 3592): Hamvasztásos temetkezés. 15-x éves, meghatározhatatlan nemü egyén. A töredezettség mértéke közepes (1-5 cm), a kiégetettség a tökéletestől a krétaszerüig változik. A kalcinált csontok tömege $64 \mathrm{~g}$, mennyisége körülbelül 10 darab.

110. sír (Ltsz. 3599): Csontvázas temetkezés. 35-40 éves nő. A koponya és az állkapocs töredékes és hiányos, a váz hiányos. A koponya alakja felülnézetben birsoid. A homlok meredek, a nyakszirt ívelt. A lambdavarrat jobb oldalán sok nagy varratcsont látható. A becsült testmagasság 157,0 cm. Perforatio fossa olecranii humeri (Farkas 1975). 
6. táblázat folytatása - Table 6 cont'd.

\begin{tabular}{|c|c|c|c|c|c|c|c|}
\hline \multirow{2}{*}{$\begin{array}{l}\text { Régészeti k. - Arch. c. } \\
\text { Sírszám-Grave no. }\end{array}$} & & \multirow[b]{2}{*}{172} & \multicolumn{2}{|c|}{ Halomsíros } & \multirow[b]{2}{*}{$120 / b$} & \multicolumn{2}{|c|}{ Nagyrév - Haloms. } \\
\hline & & & 173 & $120 / \mathrm{a}$ & & 24 & 84 \\
\hline Rítus - Rite & $\begin{array}{l}\text { Egy egyén - One } \\
\text { person } \\
\text { Két egyén - Two } \\
\text { persons } \\
\text { Nem vizsgálható - } \\
\text { Non-examinable }\end{array}$ & + & + & + & + & + & + \\
\hline $\begin{array}{l}\text { Töredezettség } \\
\text { mértéke - Measure } \\
\text { of fragments }\end{array}$ & $\begin{array}{l}x-1 \mathrm{~cm} \\
1-5 \mathrm{~cm} \\
5-x \mathrm{~cm}\end{array}$ & + & + & + & + & + & + \\
\hline $\begin{array}{l}\text { A kiégettség mértéke } \\
\text { - Burning level }\end{array}$ & $\begin{array}{l}\text { Krétaszerü - Cretaceous } \\
\text { Tökéletestöl krétaszerüig- } \\
\text { From perfect to cretac. } \\
\text { Tökéletes - Perfect } \\
\text { Részenként tökéletes - } \\
\text { Perfect in parts } \\
\text { Tökéletlen - Imperfect }\end{array}$ & + & + & + & + & + & + \\
\hline $\begin{array}{l}\text { Mennyiség (db) - } \\
\text { Quantity (pieces) }\end{array}$ & $\begin{array}{l}\mathrm{x}-10 \\
10-50 \\
\approx 50 \\
100-\mathrm{x}\end{array}$ & + & + & + & + & + & + \\
\hline $\begin{array}{l}\text { Robuszticitás - } \\
\text { Robusticity }\end{array}$ & $\begin{array}{l}\text { Gyenge - Weak } \\
\text { Közepes - Medium } \\
\text { Kiemelkedő - Strong } \\
\text { Eröteljes - Very } \\
\text { strong } \\
\text { Nem vizsgálható - } \\
\quad \text { Non-examinable }\end{array}$ & + & + & + & + & + & + \\
\hline $\begin{array}{l}\text { Izomreliefek - } \\
\text { Muscle attachment } \\
\text { sites }\end{array}$ & $\begin{array}{l}\text { Gyenge - Weak } \\
\text { Közepes - Medium } \\
\text { Erős - Strong } \\
\text { Nem vizsgálható - } \\
\quad \text { Non-examinable }\end{array}$ & + & + & + & + & + & + \\
\hline Tömeg - Weight (g) & & 32 & 234 & 298 & 194 & 46 & 436 \\
\hline
\end{tabular}

112. sír (Ltsz. 3601): Hamvasztásos temetkezés. 20-60 éves, meghatározhatatlan nemü egyén. A csontok robuszticitása és az izomreliefek kifejezettsége közepes. A töredezettség mértéke közepes (1-5 cm), a kiégetettség krétaszerü. A medencetájék kevésbé kiégett, mint a váz. A kalcinált csontok tömege 580 g, mennyisége meghaladja a 100 darabot.

113. sír (Ltsz. 3602): A régészeti dokumentáció szerint hamvasztásos temetkezés, ezzel szemben a csontokon égésnyom nem látható. Újszülött gyermek. A koponya és a váz töredékes-hiányos, állkapocs nincs.

120a. sír (Ltsz. 3606): Hamvasztásos temetkezés. Infans I. korú (1-6 éves) gyermek és 15-45 éves felnőtt kalcinált csonttöredékei. A felnőtt egyén robuszticitása és az izomreliefek kifejezettsége közepes. A fragmentáltság mértéke közepes $(1-5 \mathrm{~cm})$, a 
kiégetettség részenként tökéletes. A koponya kevésbé kiégett, mint a váz. A hamvak tömege 298 g, a kalcinált csontok mennyisége körülbelül 50 darab.

120b. sír (Ltsz. 3607): Hamvasztásos temetkezés. 5-14 éves gyermek. A fragmentáltság mértéke közepes $(1-5 \mathrm{~cm})$, a kiégetettség a tökéletestől a krétaszerüig változik. A koponya kiégettsége tökéletes, a medence kevésbé kiégett. A kalcinált csontok tömege 194 g, mennyisége körülbelül 50 darab.

7. táblázat. A késő bronzkori hamvasztásos temetkezések jellemzői. Table 7. Summary of the characteristics of Late Bronze Age cremation burials.

\begin{tabular}{|c|c|c|c|}
\hline & & $\mathrm{N}$ & $\%$ \\
\hline Rítus - Rite & $\begin{array}{l}\text { Egy egyén - One person } \\
\text { Két egyén - Two persons }\end{array}$ & $\begin{array}{r}17 \\
3\end{array}$ & $\begin{array}{l}85,0 \\
15,0\end{array}$ \\
\hline $\begin{array}{l}\text { Töredezettség mértéke - } \\
\text { Measure of fragments }\end{array}$ & $\begin{array}{l}x-1 \mathrm{~cm} \\
1-5 \mathrm{~cm} \\
5-x \mathrm{~cm}\end{array}$ & $\begin{array}{r}1 \\
19 \\
0\end{array}$ & $\begin{array}{r}5,0 \\
95,0 \\
0,0\end{array}$ \\
\hline $\begin{array}{l}\text { A kiégettség mértéke - } \\
\text { Burning level }\end{array}$ & $\begin{array}{l}\text { Krétaszerü - Cretaceous } \\
\text { Tökéletestöl krétaszerüig - From perfect to cretaceous } \\
\text { Tökéletes - Perfect } \\
\text { Részenként tökéletes - Perfect in parts } \\
\text { Tökéletlen - Imperfect }\end{array}$ & $\begin{array}{l}2 \\
4 \\
1 \\
9 \\
4\end{array}$ & $\begin{array}{r}10,0 \\
20,0 \\
5,0 \\
45,0 \\
20,0\end{array}$ \\
\hline $\begin{array}{l}\text { Mennyiség (db) - } \\
\text { Quantity (pieces) }\end{array}$ & $\begin{array}{l}\mathrm{x}-10 \\
10-50 \\
\approx 50 \\
100-\mathrm{x}\end{array}$ & $\begin{array}{l}3 \\
5 \\
7 \\
5\end{array}$ & $\begin{array}{l}15,0 \\
25,0 \\
35,0 \\
25,0\end{array}$ \\
\hline $\begin{array}{l}\text { Robuszticitás - } \\
\text { Robusticity }\end{array}$ & $\begin{array}{l}\text { Gyenge - Weak } \\
\text { Közepes - Medium } \\
\text { Kiemelkedő - Strong } \\
\text { Eröteljes - Very strong } \\
\text { Nem vizsgálható - Non-examinable }\end{array}$ & $\begin{array}{l}2 \\
8 \\
0 \\
4 \\
6\end{array}$ & $\begin{array}{r}14,3 \\
57,1 \\
0,0 \\
28,6 \\
30,0\end{array}$ \\
\hline $\begin{array}{l}\text { Izomreliefek - Muscle } \\
\text { attachment sites }\end{array}$ & $\begin{array}{l}\text { Gyenge - Weak } \\
\text { Közepes - Medium } \\
\text { Erös - Strong } \\
\text { Nem vizsgálható - Non-examinable }\end{array}$ & $\begin{array}{l}2 \\
7 \\
4 \\
7\end{array}$ & $\begin{array}{l}15,4 \\
53,8 \\
30,8 \\
35,0\end{array}$ \\
\hline \multicolumn{2}{|c|}{ Átlagos tömeg $(\mathrm{g})$ - Average weight $(\mathrm{g})$} & \multicolumn{2}{|c|}{$273 \mathrm{~g}$} \\
\hline
\end{tabular}

125. sír (Ltsz. 3612): Csontvázas temetkezés. 0-2 éves gyermek. A koponya és a váz töredékes és hiányos, állkapocs nincs.

142. sír (Ltsz. 3622): Hamvasztásos temetkezés. 7-18 éves egyén. A töredezettség mértéke közepes (1-5 cm), a kiégetettség tökéletlen. A medence- és a térdízület kevésbé jól kiégett, mint a váz többi része. A kalcinált csontok tömege $222 \mathrm{~g}$, mennyisége körülbelül 50 darab.

147. sír (Ltsz. 3625): Csontvázas temetkezés. 2-4 éves gyermek. Töredékes-hiányos koponya és váz, az állkapocs hiányzik.

148. sír (Ltsz. 3626): Hamvasztásos temetkezés. 10-30 éves, meghatározhatatlan nemü egyén. A felnőtt robuszticitása közepes. A töredezettség mértéke közepes $(1-5 \mathrm{~cm})$, a kiégetettség részenként tökéletes. A hamvak tömege $58 \mathrm{~g}$, a kalcinált csontok mennyisége 10 és 50 darab közötti. 
155. sír (Ltsz. 3631): Csontvázas temetkezés. 25-30 éves férfi (4. ábra). A koponya, az állkapocs és a váz egyaránt ép. A koponya alakja felülnézetben ovális alakú, a homlok és a nyakszirt ívelt, a szemüreg szögletes, az orr keskeny, az orrüreg alsó pereme anthropin, a spina nasalis anterior 4. fokozatú, a fossa canina közepesen mély. Taxonómia: mediterrán-nordikus (Farkas 1975). A becsült testmagasság 157,6 cm. A bal falcsonton poroticus fázisú cribra orbitalia látható.
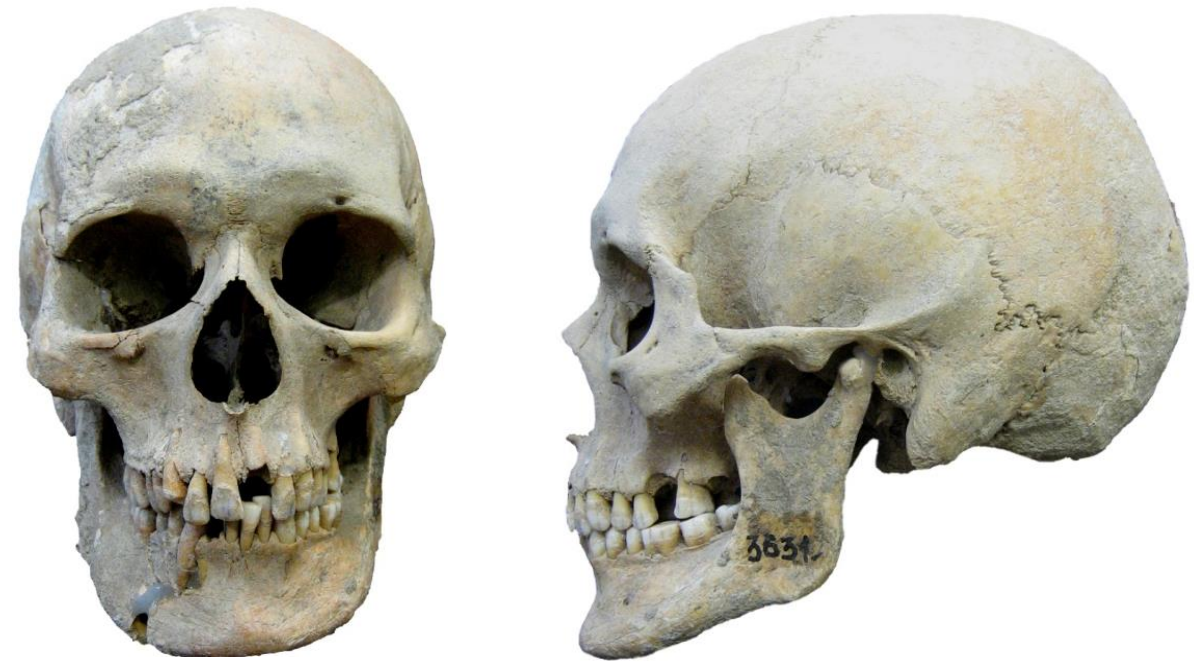

4. ábra: Rákóczifalva-Kastélydomb 155. sír (Ltsz. 3631), Halomsíros kultúra. 23-39 éves férfi, elöl- és oldalnézet.

Fig. 4: Rákóczifalva-Kastélydomb, Grave 155 (Inv. No. 3631), 23-29-year old male, Tumulus culture, frontal and lateral view of the skull.

163. sír (Ltsz. 3636): Csontvázas temetkezés. 21-24 éves nő. A koponya töredékes és hiányos, az állkapocs hiányzik, a váz ép. A lambdavarratban Worm-féle varratcsontok jelentkeztek. A becsült testmagasság szerint 146,66 cm. A csontok között egy 5-6 éves gyermek felkar- és sípcsontja is volt.

164. sír (Ltsz. 3637): Hamvasztásos temetkezés. 20-30 éves férfi(?). A csontok robuszticitása és az izomreliefek kifejezettsége erős. A töredezettség mértéke közepes (1$5 \mathrm{~cm}$ ), a kiégetettség a tökéletestöl a krétaszerüig változik. Az ágyéki csigolyák kevésbé jól kiégettek, mint a váz többi része. A hamvak tömege 500 g, a kalcinált csontok mennyisége meghaladja a 100 darabot.

170. sír (Ltsz. 3643): Hamvasztásos temetkezés. 30-60 éves, meghatározhatatlan nemü egyén. A csontok robuszticitása és az izomreliefek kifejezettsége közepes. A fragmentáltság mértéke közepes $(1-5 \mathrm{~cm})$, a kiégetettség részenként tökéletes. A kiégettségben a váz különböző részei és a koponya között nincs jelentős eltérés. A hamvak tömege 298 g, a kalcinált csontok mennyisége 50 és 100 darab közötti.

172. sír (Ltsz. 3644): Hamvasztásos temetkezés. 2-3 éves gyermek. A hamvak közül elökerült egy felnőtt egyén nagyőrlő fogának töredéke is. A töredezettség közepes (1-5 $\mathrm{cm})$, a kiégetettség tökéletlen. A medencetájék kevésbé kiégett, mint a váz többi része és a koponya. A hamvak tömege $32 \mathrm{~g}$, a kalcinált csontok mennyisége 10 és 50 darab közötti. 
173. sír (Ltsz. 3645): Hamvasztásos temetkezés. 20-60 éves, meghatározhatatlan nemü egyén. A csontok robuszticitása és az izomreliefek kifejezettsége erős. A fragmentáltság mértéke közepes $(1-5 \mathrm{~cm})$, a kiégetettség részenként tökéletes. Az alkar csontjai kevésbé kiégetettek, mint a koponya vagy a váz többi része. A kalcinált csontok tömege 234 g, mennyisége körülbelül 50 darab.

A bizonytalan régészeti besorolású, kora vagy késö bronzkori sírok

17. sír (Ltsz. 3523): Csontvázas temetkezés. 35-50 éves férfi. A koponya és az állkapocs töredékes és hiányos, a váz hiányos. Az orr keskeny, az orrüreg alsó pereménél fossa praenasalis figyelhető meg. A spina nasalis anterior a Broca szerinti skálán 1. fokozatú, alveolaris prognathia nincs, a fossa canina közepesen mély. Az izomtapadási helyek a vázon mindenhol erősen kifejezettek. Enthesopathia látható mindkét sarokcsonton, a sípcsontok érdességén és a bal térdkalácson.

34. sír (Ltsz. 3539): Csontvázas temetkezés. 20-30 éves nő. A koponya, az állkapocs és a váz is töredékes és hiányos.

63. sír (Ltsz. 3561): Csontvázas temetkezés. A koponya ép, az állkapocs hiányos, a váz töredékes és hiányos. 40-45 éves férfi (5. ábra). A koponya alakja felülnézetben pentagonoid, a szemüreg kerek, az orr széles. Az orrüreg alsó peremén sulcus praenasalis látható. A spina nasalis anterior 3. fokozatú, az alveoláris prognathia kicsi, a homlok ívelt, a fossa canina közepesen mély. A koronavarratban egy, a lambdavarratban sok nagy varratcsont figyelhető meg. Taxonómia: nordikus-atlantomediterrán (Farkas 1975). A két jobb felső kisőrlő fogkoronájának nagy része lekopott.
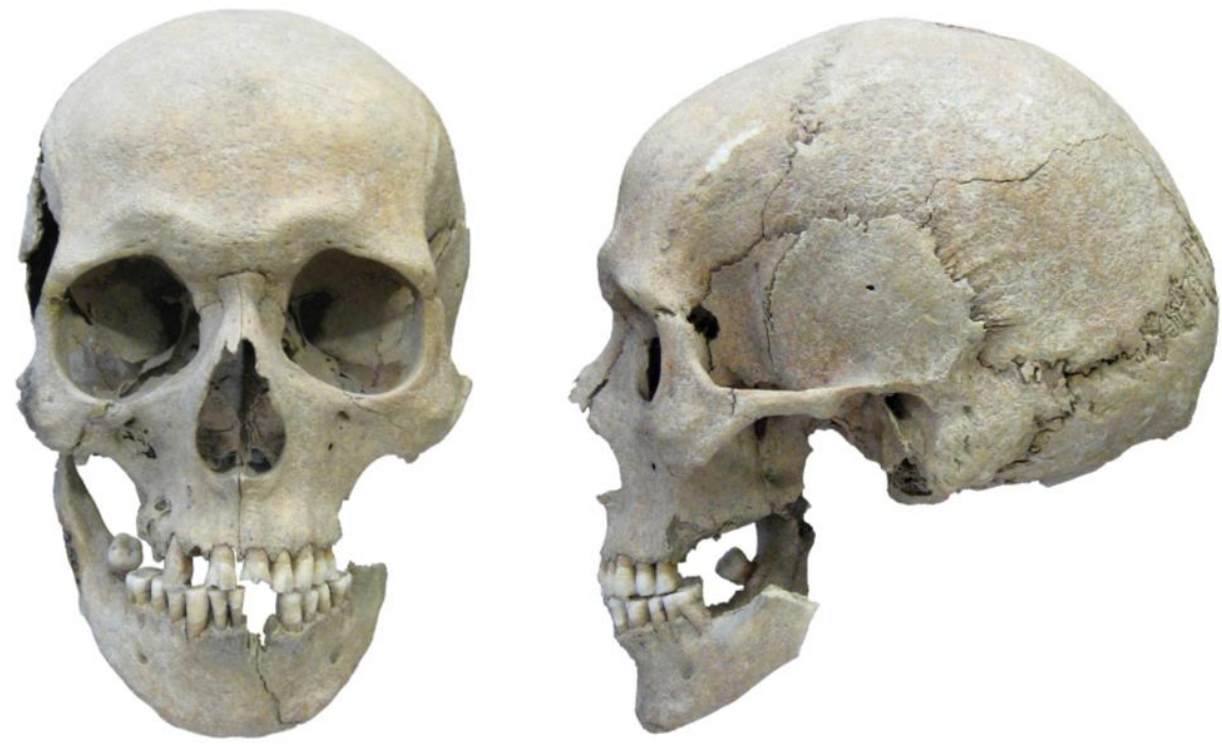

5. ábra: Rákóczifalva-Kastélydomb, 63. sír (Ltsz. 3561), adultus férfi. Nagyrév vagy Halomsíros kultúra. Elöl- és oldalnézet.

Fig. 5: Rákóczifalva-Kastélydomb, Grave 63 (Inv. No. 3561), adult male, Tumulus culture. Frontal and lateral view of the skull. 
85. sír (Ltsz. 3576): Csontvázas temetkezés. 20-25 éves. A koponya, az állkapocs és a váz is töredékes és hiányos. Több megfigyelhető nemi jellege nőies, a nem meghatározása ennek ellenére nem lehetséges.

93. sír (Ltsz. 3583): Csontvázas sír. 6-7 éves gyerek. A koponya töredékes, az állkapocs töredékes és hiányos, a váz hiányos. Mindkét szemüregben cribra orbitalia (cribroticus forma) látható.

146. sír (Ltsz. 3624): Csontvázas temetkezés. 2-3 éves gyermek. A koponya töredékes-hiányos, állkapocs nincs, a váz hiányos. A jobb szemüregben poroticus fázisú cribra orbitalia látható.

151. sír (Ltsz. 3629): Csontvázas temetkezés. 30-35 éves nő. A koponya, az állkapocs és a váz egyaránt töredékes-hiányos. A csontok között volt egy gyermek csípöcsontdarabja is. A becsült testmagasság 156,2 cm.

\section{Az eredmények megvitatása, következtetések}

A kora bronzkori sírok vizsgálata során összesen 5 egyén maradványait elemeztem. Az eredményekből a kis esetszám miatt a népességre vonatkozó jelentős következtetés nem vonható le.

A késő bronzkori egyének vizsgálata során 37 sírból 40 egyén maradványait különítettem el. A temető elemzésekor kiderült, hogy a felnőttkort el nem érők meglehetősen nagy számban fordultak elő (2-3. táblázat). Ezt a tényt Farkas (1975) is megemlítette munkájában, hozzátéve egyúttal azt is, hogy véleményét kizárólag a csontvázas sírok vizsgálatának eredményeire alapozta. A felnőttek hiányzó sírjait véleménye szerint a hamvasztásos temetkezések között kell keresni (Farkas 1975). Farkas a kandidátusi disszertációjában a gyermekek becsült életkorára vonatkozóan a jelen kéziratban megadottnál valamivel tágabb korintervallumot használt. A különbség oka nagy valószínüleg az utóbbi évtizedekben lezajlott antropológiai módszertani fejlődés, amely lehetővé tette a jelen kutatómunka során újabb - és reményeink szerint - pontosabb életkorbecslési metodikák használatát.

A hamvasztásos sírok vizsgálatának eredményei alapján megállapítható, hogy bár a késő bronzkori népességben a felnőttek sírjainak száma a kalcinált csontok vizsgálata után valóban megnövekedett, a gyermekek és fiatalkorúak aránya a temetőben így is nagynak tekinthetö. A bronzkori népességekre vonatkozó hazai embertani irodalmat áttekintve megállapítható, hogy mindössze egyetlen olyan leírt sorozat ismert, amelyben hasonlóan magas a felnőttkort el nem érők aránya, mint Rákóczifalván, ez JánoshidaBerek (Hajdu 2008). A többi feltárt késő bronzkori temetőben a felnőttkort el nem érők sírjainak kis száma valószínüleg a gyermeksírok sekélységének köszönhető, valamint annak a ténynek, hogy a gyermekek csontjai jóval vékonyabbak, így a posztmortem folyamatok jóval nagyobb kárt okozhatnak a gyermekek csontjaiban, mint a felnőttek csontjaiban.

A férfiak és nők aránya a temetőben kiegyenlített, azonban a meghatározhatatlan nemü egyének nagy száma ebben az esetben nem hagyható figyelmen kívül. A vizsgálható késő bronzkori hamvasztásos sírokban a nemek és a korcsoportok egymáshoz viszonyított arányát a kalcinált csontok töredezettsége miatt nem lehetett vizsgálni.

A késő bronzkori népesség metrikus adatok (4-5. táblázat) alapján történő jellemzése és más népességekkel történő összehasonlító elemzése a leletek rossz megtartása, a mérhetö koponyák alacsony száma miatt nem lehetséges. 
A késő bronzkori hamvasztásos temetkezések egy sír kivételével minden esetben közepes nagyságú (1 és $5 \mathrm{~cm}$ közötti) csonttöredékeket tartalmaztak (7-8. táblázat). A kiégetettség mértéke, a csonttöredékek mennyisége, a koponya, illetve a váz különböző részeinek kiégetettségében megfigyelhető különbségek nagymértékben variáltak. A hamvak átlagos tömege $273 \mathrm{~g}$ volt, azonban öt esetben a vizsgálható csonttöredékek tömege, illetve mennyisége annyira kevés volt, hogy ez jelentősen módosította a hamvak átlagos tömegére kapott értéket.

A hamvasztásos temetkezések döntő többsége egyetlen személy maradványait tartalmazta. Három esetben a hamvasztott gyermekek maradványai felnőttek kalcinált csontjaival együtt kerültek elő. A lehetséges rokoni kapcsolat a kalcinált csontanyag megtartásából adódóan nem vizsgálható, bár a 47. sírból egy nő és egy gyermek hamvai együtt kerültek elö, ez talán utalhat anya-gyermek kapcsolatra is. Ugyanakkor ezeknél a síroknál a második egyénből meglévő kevés töredék miatt a hamvasztás helyén, a feltárásnál, a tisztításnál történt bekeveredés sem zárható ki teljes mértékben.

Tanulmányommal a 80 éves Gyenis Gyulát és Marcsik Antóniát köszöntöm.

A rákóczifalvi leletanyag elemzését Kovács Tibor felkérésére végeztem el, jelen tanulmányomat Kovács Tibor emlékének ajánlom.

Köszönetnyilvánítás: Köszönettel tartozom Marcsik Antóniának, hogy lehetővé tette RákóczifalvaKastélydomb bronzkori leleteinek feldolgozását, Molnár Erikának pedig, hogy elvégezte a leletanyag vizsgálatra való előkészítését, továbbá Balassa Tímeának a feldolgozás során nyújtott segítségéért. A kutatás az FK128013 azonosító számú projekt keretében, valamint az MTA Bolyai János kutatási ösztöndíja támogatásával valósult meg.

\section{Irodalom}

Aufderheide, A., Rodriguez-Martin, C. (1998): The Cambridge Encyclopedia of Human Paleopathology. Cambridge University Press, Cambridge, UK.

Bernert, Zs. (2005): Paleoantropológiai programcsomag. Folia Anthropologica, 3: 71-74.

Bernert, Zs., Évinger, S., Hajdu, T. (2007): New data on the biological age estimation of children using bone measurements based on historical populations from the Carpathian Basin. Annales Historico-Naturales Musei Nationalis Hungarici, 99: 199-206.

Bernert, Zs., Évinger, S., Hajdu, T. (2008): Adatok a gyermekek életkorbecsléséhez a Kárpátmedencei történeti népességek gyermekhalottainak csontméretei alapján. Anthropologiai Közlemények, 49: 43-50.

Chochol, J. (1961): Analyse menschlicher Brandreste aus den Lausitzer Gräberfeldern in Ushi nad Laben-Strečkov II. und in Žirovice, Bezirk Cheb. In: Plesl, E. (Ed.) Lužichea kultúra v seveozápadnich Čechach. Praha. pp. 273-293.

Csalog, Zs. (1963a): Rákóczifalva-Kastélydomb (Kom. Szolnok, Kr. Szolnok). Archaeologiai Értesitö, 90: 298

Csalog, Zs. (1963b): Rákóczifalva-Kastélydomb (Szolnok m., Szolnoki j.). Régészeti Füzetek, I(16): 16-17.

Csányi, M. (1983): A nagyrévi kultúra leletei a közép-tisza vidékröl. Szolnok Megyei Múzeumi Évkönyv, 1982/83: 33-65.

Éry, K., Kralovánszky, A., Nemeskéri, J. (1963): Történeti népességek rekonstrukciójának reprezentációja. Anthropologiai Közlemények, 7: 41-90. 
Farkas, Gy. (1975): A Dél-Alföld őskorának paleoantropológiája. Kandidátusi értekezés. József Attila Tudományegyetem, Szeged.

Farkas, Gy. (1976a): Results of the evaluation of prehistoric finds from the South of the Great Hungarian Plain. Anthropologie, 14(3): 227-229.

Farkas, Gy. (1976b): The problem of the coincidence of archaeological and anthropological sexdeterminations in case of Prehistoric finds in the Southern Great Hungarian Plain. Acta Biologica Szegediensis, 22(1-4): 137-143.

Farkas, Gy. (1977a): A Dél-Alföld őskorának paleoantropológiája. Kandidátusi értekezés tézisei. Anthropologiai Közlemények, 21: 115-132.

Farkas, Gy. (1977b): Anthropological outlines of the prehistory of the Southern part of the Great Hungarian Plain and of Northern Jugoslavia. Acta Biologica Szegediensis, 23(1-4): 139-167.

Farkas, Gy., Lipták, P. (1971): A Tápé mellett feltárt késő bronzkori temető antropológiai értékelése. Anthropologiai Közlemények, 15: 3-18.

Farkas, Gy., Lipták, P. (1975): Anthropologische Auswertung des bronzezeitlichen Gräberfeldes bei Tápé. In: Trogmayer, O. (Ed.) Das bronzezeitliche Gräberfeld bei Tápé. Fontes Archaeologici Hungariae, 17: 229-267.

Farkas, Gy., Marcsik, A. (1975): Anatomical variations and palaeopathological observations in Prehistoric series. Acta Biologica Szegediensis, 21(1-4): 147-163.

Ferembach, D., Schwidetzky, I., Stloukal, M. (1979): Empfehlungen für die Alters- und Geschlechtsdiagnose am Skelett. Homo, 30: 1-32.

Fischl, K.P., Hajdu, T. (2016): Mezőnagymihály - Nagyecsér-Észak lelőhely bronzkori temetkezései. Tisicum, 25: 141-160.

Hajdu, T. (2008): A késő-bronzkori halomsíros kultúra Jánoshida-Berek lelőhelyen feltárt temetőjének embertani vizsgálata. Anthropologiai Közlemények, 49: 65-82.

Hajdu, T. (2012a): A bronzkori Füzesabony és Halomsíros kultúra népességének biológiai rekonstrukciója. PhD disszertáció. ELTE TTK Embertani Tanszék, Budapest.

Hajdu, T. (2012b): A bronzkori Füzesabony és Halomsíros kultúra népességének biológiai rekonstrukciója. Doktori értekezés tézisei. Anthropologiai Közlemények, 53: 133-140.

Hänsel, B., Kalicz, N. (1986): Das bronzezeitliche Gräberfeld von Mezöcsát, Kom. Borsod, Nordostungarn. Bericht der Römish-Germanischen Komission, 67: 6-75.

Işcan, M.Y., Loth, S.R., Wright, R.K. (1984): Age estimation from the rib by phase analysis: white males. Journal of Forensic Science, 29: 1094-1104. DOI: 10.1520/JFS11776J

Işcan, M.Y., Loth, S.R., Wright, R K. (1985): Age estimation from the rib by phase analysis: white females. Journal of Forensic Science, 30: 853-863. DOI: 10.1520/JFS11018J

Kovács, T. (1981): Zur problematik der Entstehung der Hügelgräber. Slovenská Archeológia, 29(1): 87-96.

Köhler, K., Hajdu, T. (2008): A Szurdokpüspöki-Hosszú-dűlő lelőhelyen feltárt temetkezések vizsgálatának eredményei. Folia Anthropologica, 7: 53-61.

Köhler, K., Hajdu, T. (2009): Die anthropologischen Untersuchungen der Skelettfunde aus Szurdokpüspöki-Hosszú-dűlő. In: Guba, Sz., Bácsmegi, G. (Eds): Eine dreifache Bestattung der Hügelgräberkultur aus der gemarkung von Szurdokpüspöki (NO-Ungarn). Analele Banatului SN, Arheologie - Istorie, 17: 129-139.

Kővári, I. (2008): Az Alföld öskori népességeinek megitélése kraniometriai elemzésük révén. $\mathrm{PhD}$ disszertáció. Debreceni Egyetem, Debrecen.

Kővári, I., Marcsik, A. (2004): Különleges melléklettel eltemetett késő bronzkori csontvázlelet vizsgálata. In: Ilon, G. (Szerk.) $M \Omega M \Omega \Sigma$ 3. Szombathely-Bozsok. pp. 207-209.

Lipták, P., Marcsik, A. (1975): Skeletal remains of the Avar Period and 10th Century cemetery excavated at Rákóczifalva-Kastélydomb. Acta Biologica Szegediensis, 21(1-4): 165-179.

Martin, R., Saller, K. (1957): Lehrbuch der Anthropologie. 3. Auflage. Gustav Fischer, Stuttgart.

Meindl, R.S., Lovejoy, C.O. (1985): Ectocranial suture closure: A revised method for the determination of skeletal age at death based on the lateral-anterior sutures. American Journal of Physical Anthropology, 67: 51-63. 
Nemeskéri, J., Harsányi, L. (1968): A hamvasztott csontvázleletek vizsgálatának kérdései. Anthropologiai Közlemények, 12: 99-116.

Ortner, D.J. (2003): Identification of pathological conditions in human skeletal remains. Academic Press, Amsterdam.

Pap, I., Fóthi, E., Józsa, L., Bernert, Zs., Hajdu, T., Molnár, E., Bereczki, Zs., Lovász, G., Pálfi, Gy. (2009): Történeti embertani protokoll - A régészeti feltárások embertani anyagainak kezelésére, alapszintü feldolgozására és elsődleges tudományos vizsgálatára. Anthropologiai Közlemények, 50: 108-123.

Schour, J., Massler, M. (1941): The development of the human dentition. Journal of the Americal Dental Association, 28: 1153-1160.

Sjøvold, T. (1990): Estimation of stature from long bones utilizing the line of organic correlation. Human Evolution, 5: 431-447. DOI: 10.1007/BF02435593

Stloukal, M., Hanáková, H. (1978): Die Lange der Langsknochen altslawischer Bevölkerungen unter besonderer Berücksichtigung von Wachstumsfragen. Homo, 29: 53-69.

Szathmáry, L. (1979): A Déri Múzeum bronzkori csontvázleleteinek embertani vizsgálata. A Debreceni Déri Múzeum Évkönyve, 4: 39-57.

Todd, T.W. (1920): Age changes in the pubis bone: I. The male white pubis. American Journal of Physical Anthropology, 3: 285-334.

Tóth, G. (2013): Bronzkori halomsír embertani anyaga Jánosházáról. Vasi Szemle, 67: 471-474

Tóth, G., Melis, E., Ilon, G. (2016): A ménfőcsanaki feltárás (2009-2011) bronzkori leletanyagának embertani és azokkal összefüggő régészeti eredményei. In: Csécs, T., Takács, M. (Szerk.) Beatus homo qui invenit sapientiam. Ünnepi kötet Tomka Péter 75. születésnapjára. Győr. pp. 737-755.

Ubelaker, D.H. (1978): Human skeletal remains: excavation, analysis, interpretation. Taraxacum, Washington.

Zoffmann, K.Zs. (1995): A Nagyrév és Vatya kultúrák hamvasztott csontvázleletei Szigetszentmiklós-Felsőtag lelöhelyröl. In: Kalicz, N., Schreiber, R. (Szerk.) Bronzkori urnatemetö Szigetszentmiklós határában. Ráckevei Múzeumi Füzetek, 2: 170-180.

Zoffmann, K.Zs. (2004): Újabb öskori embertani leletek Kelet-Magyarországról. A Debreceni Déri Múzeum Évkönyve, 2004: 83-94.

Zoffmann, K.Zs. (2005): Az Oszlár-Nyárfaszög lelőhelyen feltárt késő-bronzkori embertani leletek. In: Koós, J. - A késő bronzkor történeti kérdései Északkelet-Magyarországon. Különös tekintettel az oszlári ásatás eredményeire. PhD doktori értekezés, ELTE Régészettudományi Intézet, Budapest.

$\begin{array}{ll}\text { Levelezési cím: } & \text { Hajdu Tamás } \\ \text { Mailing address: } & \text { Embertani Tanszék } \\ & \text { Eötvös Loránd Tudományegyetem } \\ & \text { Pázmány P. s. 1/c. } \\ & \text { H-1117 Budapest } \\ & \text { Hungary } \\ & \text { Embertani Tár } \\ & \text { Magyar Természettudományi Múzeum } \\ & \text { Ludovika tér 2. } \\ & \text { H-1083 Budapest } \\ & \text { Hungary } \\ & \text { tamas.hajdu@ @ttk.elte.hu } \\ & \text { hajdu.tamas@nhmus.hu }\end{array}$

